\title{
5. Sharing global regulatory space: transatlantic coordination of the G20 OTC derivatives reforms ${ }^{1}$
}

\author{
Heikki Marjosola
}

\subsection{INTRODUCTION}

The governance of the global market for over-the-counter (OTC) derivatives has undergone a metamorphosis. Set in motion by the Group of Twenty (G20) 2009 summit in Pittsburgh, the regulatory overhaul has transformed what used to be a relatively harmonious and transnational legal regime into a global regulatory space which - like all regulatory spaces (Hancher and Moran 1998) - is highly contested. In the light of the hypotheses developed in Chapter 1 of this book, this chapter evaluates the implementation and coordination of the globally agreed derivatives reforms in and between the United States and the European Union (for earlier research on this topic, see Godwin et al. 2017). The chapter focuses specifically on the possible implications of coordination challenges for regulatory structures. The hypothesis is that, together with the risk of regulatory arbitrage, regulatory competition contributes to regulatory centralisation in internal regulatory structures.

Prompted by the Global Financial Crisis, the G20 initiatives aimed to increase the transparency and stability of derivative markets, particularly by centralising the execution of trading within regulated trading venues and by imposing mandatory clearing, reporting and risk-management requirements. However, instalment of the new governance system has been cumbersome. Much of the consensus reached under the G20 umbrella was lost when soft principles and policy goals were translated into hard rules. As section 5.2 will show, failures in coordination have resulted in an uneven regulatory playing field characterised by jurisdictional conflicts, inconsistencies, regulatory overlaps and gaps (Carney 2013, p. 15). The Financial Stability Board (FSB), mandated by the G20 to oversee and coordinate the implementation of the reforms, has also admitted that due to the unprecedented scale and complexity of the reforms and unforeseen challenges the implementation "has taken longer than 
originally intended" (FSB 2017, p. 3). Ten years after the Pittsburgh summit, the reforms are still to be completed (FSB 2018).

The delay is partly explained by the fact that the United States and the European Union ended up locking themselves in a "transatlantic regulatory turf war" (Stafford 2014). This chapter analyses this transatlantic conflict as a coordination challenge typical of shared regulatory spaces. Situations in which several agencies with overlapping and conflicting mandates are forced to share authority and responsibility are common in national contexts (Freeman and Rossi 2011). This is not often the case in the global context, where regulatory sovereignty continues to be seen as a "territorial prerogative" (Buxbaum 2002, p. 933; see also Brummer 2010). However, the regulatory space for global derivative markets resists neat jurisdictional partitioning. Indeed, the cross-Atlantic dialogues on OTC derivatives regulation have rightly been labelled 'joint jurisdiction’ issues (CFTC 2013a).

Two important factors have contributed to the 'shared' nature of the global regulatory space for OTC derivatives. First, unlike rules such as those on capital adequacy, which are entity-specific, many of the new rules target derivative contracts themselves (e.g. mandatory clearing and collateralisation of contracts). Such rules apply to both sides of the contract. The problem is that when the contracting parties are from different jurisdictions it is not always clear which rules apply. For instance, around 80 per cent of credit derivative transactions had a cross-border element in 2012 (Barnier 2013). At the time Lehman Brothers filed for bankruptcy, it had hundreds of thousands of derivative contracts outstanding with around 8,000 different counterparties around the globe (Hull 2011, p. 3).

Second, the shared regulatory space has emerged as a by-product of jurisdictional contestation. Section 5.2 explains how the use of certain unilateral regulatory strategies by the EU and the US - consisting of extraterritoriality, conditional deference and (direct and indirect) protectionism - have contributed to the creation of the global regulatory space. These strategies are key to understanding the emergence and dynamics of this regulatory space and its implications for regulatory structures. Much of the unilateralism has been justified by the need to contain the risks of regulatory competition and regulatory arbitrage, that is, the relocation of regulated activities to jurisdictions with less costly or more accommodating rules.

Section 5.3 analyses how the shared and highly contested nature of this novel regulatory space affects regulatory structures. It argues that the reforms have indeed increased pressure to centralise (vertically) and to consolidate (horizontally) regulatory authority, especially within the EU. Section 5.4 briefly discusses the limits of unilateral regulatory strategies from a more normative perspective, also considering certain future options and trajectories. Section 5.5 concludes. 


\subsection{OTC DERIVATIVES AND THE REGULATORY REFORM}

\subsubsection{The Context of the Reform}

Derivatives are financial instruments the value of which depends on the performance and price of a reference asset, rate or index, or some other underlying variable. Derivatives can hedge against negative price movements or unfavourable events (such as a rise in fuel prices, or debtor's default) but they may also be used for speculation or arbitrage (see generally Hull 2011, pp. 10-16). Options and forwards provide the ancestral building blocks of all derivatives. A forward agreement simply sets a future time and price for buying or selling an asset, whereas an option holder has the right, but not the obligation, to buy (call option) or sell (put option) the underlying asset at a certain future time. The most common forward-based derivatives are swaps, which involve an exchange of sequential cash flows, such as fixed interest cash flows for floating interest cash flows (interest rate swaps). Credit default swaps (CDS) are a specific type of swap offering protection against default on a loan $\mathrm{(Hu}$ 1993; Hull 2011, pp. 5-8). At the most complex end, financial products may be securitised or structured so that derivatives themselves act as the underlying asset (Yen and Lai 2014, pp. 2-3).

OTC derivatives, especially CDSs, were at the centre of the 2007-2009 financial crisis (see, e.g. FCIC 2011, pp. 50-51). In its immediate aftermath, the G20 took decisive action and in 2009 issued the following statement:

All standardized OTC derivative contracts should be traded on exchanges or electronic trading platforms, where appropriate, and cleared through central counterparties by end-2012 at the latest. OTC derivative contracts should be reported to trade repositories. Non-centrally cleared contracts should be subject to higher capital requirements. (G20 2009)

The reform therefore concerned: (a) the organisation of the entire market (on-exchange vs. OTC); (b) the clearing and settlement of trades (central clearing vs. bilateral settlement); (c) the transparency of the OTC market (trade reporting); and (d) the management of payment and delivery risks for uncleared derivatives. Importantly, the G20 later updated the policy by agreeing that uncleared OTC derivatives should also be subject to mandatory collateralisation rules.

These far-reaching reforms were in particular aimed at the obscure OTC segment of the derivative markets, which had for long avoided public regulation (Partnoy 2001; Carruthers 2013). All derivatives are traded over-the-counter or through regulated exchanges. Derivative exchanges, such as the Chicago 
Board of Exchange, offer a limited number of highly standardised products, whereas the private OTC market allows for infinite customisation. In the mid-1980s, the public and exchange-traded derivative market was larger than the private OTC market, but by 2008 the latter had not only surpassed the public market but in fact was worth roughly ten times as much (Carruthers 2013). In June 2013, only 9 per cent of all derivatives were traded on exchanges (Deutsche Börse and Eurex Clearing 2014, p. 7). The G20 reforms aimed to relocate much of the private OTC market in public, transparent and regulated exchanges.

Second, whereas the private OTC market (particularly the CDS market) came close to collapsing in 2008-2009, the derivative clearing houses (central counterparties, or CCPs) navigated through the turmoil relatively unharmed. Instead of public support, the CCPs relied on their sophisticated default management systems. Centralised clearing mitigates payment and delivery risks by centralising it: the role of a CCP is to become a buyer to every seller and a seller to every buyer. CCPs have traditionally cleared all exchange-traded derivatives but only some standardised OTC derivatives. The G20 reforms aimed to expand the scope of derivative-clearing through CCPs by making it mandatory where possible, and also by making it more expensive to enter purely bilateral contracts.

Third, the financial crisis revealed that the private OTC market was prone to systematic under-collateralisation. The fact that 'margining' was left to the parties' commercial judgment meant that market participants with solid credit ratings could effectively trade without committing capital (Singh 2010). In contrast, cleared and exchange-traded derivatives are subject to mandatory margin requirements ${ }^{2}$ and CCP participants must also contribute to the CCP's default funds. To diminish the discrepancies between the public and private markets, the G20 reforms expand the scope of mandatory margining also to those OTC contracts that remain uncleared.

Although still unfinished, the reforms have significantly affected market structure. The majority of interest rate derivatives and a significant portion of CDS contracts are now centrally cleared (FSB 2017, pp. 12-13). Mandatory collateralisation of OTC contracts is meant to further push trading towards public exchanges and clearing houses. However, the regulatory push towards centralised clearing has not terminated the competition between public and private derivative markets and the flexibility and lighter cost structure of the OTC market may still trump the safety of exchange-based trading (ISDA 2013, p. 4; Kentz 2014). For instance, in 2015 the Chicago Board Options Exchange submitted a letter to the SEC highlighting the fact that despite regulatory efforts, some markets were moving away from exchanges (McCormick 2015). 


\subsubsection{From Consensus to Conflict}

The transforming market for derivatives represents a stark contrast to the pre-crisis OTC markets, which were primarily based on a transnational self-regulation regime (Braithwaite 2012). As Chapter 6 in this book shows, the terms and standards offered by the International Swaps and Derivatives Association (ISDA) as part of its Master Agreement structure have provided the dominant contractual framework for OTC transactions since the 1980s (see also Feder 2002, p. 741; Choi and Gulati 2006, p. 1140).

The implementation of the G20 initiatives has nevertheless faced several complications. To become effective, the G20 policy commitments needed to be translated into hard rules locally and regionally. For instance, the EU enacted the commitments with two key regulations: Regulation 648/2012 of the European Parliament and Council on OTC derivatives, central counterparties and trade repositories (EMIR) and Regulation 600/2014 on Markets in Financial Instruments (MiFIR). EMIR implements the mandatory clearing obligation (EMIR, Articles 4 and 5) while MiFIR requires that all sufficiently liquid and cleared OTC derivatives must be traded on regulated trading venues (MiFIR, Article 32).

In the United States, the reforms were implemented as part of the DoddFrank Wall Street Reform and Consumer Protection Act. The regulatory outcomes in the EU and the US significantly differed in detail and the divergences only grew larger as the reforms moved from the legislative to the executive stage. As a result, for example, one jurisdiction may require mandatory clearing of a certain OTC derivative contract and/or the execution of the trade on a regulated market while the other jurisdiction leaves the choice to the markets. The personal scope of regulations also differ. For instance, the EMIR exempts certain pension scheme arrangements (transitionally) and intra-group trades from the scope of the regulation, which is not the case in the US. The original EMIR rules also captured both financial and certain non-financial counterparties in much the same way, whereas in the US the scope for non-financial counterparties is more tailored. Inconsistencies have also arisen in the context of trade reporting requirements (ESMA 2013, pp. 22-23).

Conflicts concerning transaction-level rules are particularly hard to reconcile. Consider, for instance, the concentration rules, which direct certain standardised contracts into centralised clearing and on organised trading venues. These rules apply to both sides of the contract, regardless of the fact that the parties might be located in different jurisdictions. In such a situation one jurisdiction's rules cannot be followed without breaching another's (Carney 2013, p. 15). Collateralisation rules may also lead to such direct conflicts. In so far as they concern the amount of collateral that should be posted, market participants can simply meet the highest requirement, but the rules also concern 
the division between the initial and variable margins, the classes of collateral eligible and the way collateral must be segregated (Greene and Potiha 2012, p. 281).

Anticipating such conflicts, the G20 tasked the Financial Stability Board (FSB) with overseeing coordination of the reforms among national legislators and regulators. International standard-setting bodies such as the International Organization of Securities Commissions (IOSCO) and the Basel Committee on Banking Supervision (BCBS) have also developed numerous principles and standards to guide implementation. A specific OTC Derivatives Working Group representing a mass of technocratic expertise from national jurisdictions and international organisations was also set up to coordinate implementation (this body was nevertheless short-lived; see Knaack 2015).

The FSB repeatedly urged regulators to identify examples of any regulatory overlaps, inconsistencies and conflicts and to develop options for addressing the issues (FSB 2012). Most importantly, in 2013 the G20 declared that "jurisdictions and regulators should be able to defer to each other when it is justified by the quality of their respective regulatory and enforcement regimes" (G20 2013 , p. 18, emphasis added). Generally speaking, deference refers to a type of cross-border regulation in which national authorities rely on each other when carrying out the regulation or supervision of participants that operate cross-border. In practice, it may encompass various regulatory mechanisms, such as tailored exemptions, substituted compliance and various recognition and equivalence frameworks (IOSCO 2019, p. 3).

Progress towards a deference-based recognition regime has been slow and uncertain. An FSB progress report (2015, pp. 13-14) summarised the prevailing concerns:

Several authorities [...] note that unevenness in the pace of implementation of reforms, as well as inconsistencies or gaps in the application of requirements to cross-border transactions, can result in duplicative or overlapping requirements or lead to opportunities for regulatory arbitrage. Some authorities note that this, in turn, could result in market fragmentation and decreased liquidity. In addition, some emerging market and developing economies have indicated that challenges may be presented by the potential cross-border impact of reforms, such as meeting recognition/equivalence requirements of major financial centres in OTC derivatives.

Indeed, the lack of a level playing field and legal uncertainty has had unintended effects on OTC derivative markets. Reports have noted a significant drop in international trading activity and a fragmentation of liquidity along geographical lines (Artamonov 2015; ISDA 2015; FSB 2017, pp. 5-6; IIF 2019). This ongoing market fragmentation illustrates the sensitivity of OTC derivatives to legal uncertainty. Without a level playing field, a predictable 
system of deference (where market participants can comply with just one jurisdiction's rules) would be needed to stop market fragmentation.

However, such a system might also invite other kinds of strategic behaviour. Derivatives are also known for their ability to reduce the costs of, or capture profit opportunities created by, differing laws, tax rules or accounting requirements (Partnoy 1997, pp. 227-228). Such regulatory arbitrage has been relatively easy. The parties to derivative contracts may simply book transactions in their preferred jurisdiction (see Goodhart and Lastra 2010, p. 715; Riles 2014 , p. 88). The dual risks of regulatory arbitrage and market fragmentation have challenged regulators and policymakers, especially in the EU and the US. The following section illustrates how a mix of unilateral regulatory strategies helped create, and later manage, a full-blown regulatory conflict between the Atlantic neighbours.

\subsubsection{Managing Regulatory Arbitrage: Between Extraterritoriality and Deference}

To counter regulatory arbitrage risks, lawmakers in the US and EU have claimed extraterritorial authority for their rules. For instance, certain provisions in EMIR (e.g. the clearing obligation) even apply to contracts between non-EU entities when those contracts would have $a$ direct, substantial and foreseeable effect in the EU. The effect of these EMIR rules can also be extended abroad whenever it is considered necessary or appropriate to prevent the evasion of any EMIR provisions (see, e.g., Arts. 4(5) and 11(12)).

Similar rules were included in the Dodd-Frank Act. The act provides that its provisions on derivatives (the act uses the term 'swap') apply to any activities outside the United States that either (i) have a direct and significant connection with activities in, or effect on, United States commerce or that (ii) contravene rules or regulations that are necessary or appropriate to prevent the evasion of any of the act's provisions (sections 722(d) and 772(b)).

The similarity between these rules is not a coincidence. The US has a long history of exporting its capital market rules to foreign countries and the extraterritorial reach of its derivative rulebook was just a continuation of this policy motivated by a fear of regulatory arbitrage (and also the risk of losing market share). As Coffee argues, the extraterritorial application of financial regulation cannot be avoided in a world where mobile financial institutions "can easily park their higher-risk operations abroad and beyond the regulatory reach of their home country" (see Coffee 2014, p. 1260). The aggressive US stance nevertheless caused an outcry from European regulators and the financial industry, and the EU checked the US rules with a near-identical approach (Artamonov 2015, p. 12; Knaack 2015, pp. 1226-1227). 
A carrot of deference nevertheless complements the stick of extraterritoriality. In the EU, the so-called equivalence regime allows the possibility of disapplying EU rules in favour of another jurisdiction if its regulatory and supervisory regime is considered adequately 'equivalent' to that in the EU. The EU Commission, assisted by ESMA, may adopt implementing acts declaring that the legal, supervisory and enforcement arrangements of a third country are equivalent to the requirements laid down in EMIR (Art. 13(2)). Upon such determination, market participants can comply with EU requirements by being compliant with the requirements of their own, non-EU, jurisdiction (EMIR, Art. 13(3)). An equivalence decision also makes it possible for ESMA to formally recognise a third-country $\mathrm{CCP}$ or a third-country trade repository (EMIR Arts. 25(2)(a), 25(6) and 75(1)). Such entity-specific recognition levels the playing field between EU-based entities and foreign entities, allowing the latter to offer their services in the EU single market on equivalent terms. If circumstances change, the ESMA can withdraw its recognition or the Commission can review its equivalence decision. The European Commission has so far adopted 23 equivalence decisions with respect to the regulatory regimes for derivatives and central counterparties of 14 countries (7 June 2019). On the basis of these equivalence decisions, ESMA has recognised more than 30 third-country CCPs from non-EU jurisdictions, thus allowing these CCPs to provide clearing services in the EU.

Much like in the EU, the extraterritorial effect of US regulation can be lifted in the framework of substituted compliance. In its original form, substituted compliance was designed to open up the possibility for foreign actors wishing to conduct business in the US to avoid burdensome and duplicative SEC registration requirements and certain other US rules (Tafara and Peterson 2007). The more recent substituted compliance framework is designed with a view to adjusting the extraterritorial application of the Dodd-Frank Act. Under this regime, certain offshore persons and entities that might come under the scope of US rules can instead comply with regulations in their home jurisdictions (Jackson 2015). The Commodity and Futures Trading Commission (CFTC) has issued 10 comparability determinations which cover the EU, Australia, Canada, Japan, Hong Kong and Switzerland, making favourable determinations in favour of all six. The scope of the comparability determinations has nevertheless been limited, excluding many 'transaction-level' requirements. ${ }^{3}$

Such deference strategies represent an important exception to the traditional modus operandi of international financial regulation, where "each state prefers to address cross-border challenges simply by applying its own laws" (Verdier 2013, pp. 1438-1439). However, as the next section will show, getting to the actual decision can be a time-consuming and delicate process. 


\subsubsection{The Transatlantic Turf Battle Regarding CCPs}

Ideally, the stick of extraterritoriality and the carrot of deference should have led to negotiated convergence between the EU and the US, ultimately giving rise to a regime of mutual recognition. Without material differences in rules, there would be fewer risks of regulatory arbitrage and fewer effects on markets. The negotiations appeared to get off to a good start. In 2013, the parties released the so-called Path Forward statement. The agreement laid down a road map towards mutual recognition of derivative rules and outlined a package of measures for approaching common issues concerning cross-border derivatives. According to the statement, the parties would not seek to apply their rules "unreasonably" in the other jurisdiction but instead would "rely on the application and enforcement of the rules by the other jurisdiction" (CFTC 2013a). After the statement, the talks continued in different fora, both official and unofficial. Participants held several meetings in the context of the 'Financial Markets Regulatory Dialogue', which was later renamed the 'Joint EU-US Financial Regulatory Forum'. The purpose of the Forum (which has convened once or twice a year) is, among other things, to "work towards avoiding regulatory arbitrage and towards compatibility [...] of each other's standards" (Joint Statement 2016).

Despite comforting declarations and good intentions, the bargain proved to be an exceptionally hard one to strike. By September 2015, the negotiations were locked in a stalemate (Stafford 2015). The range of negotiation issues was extensive, as was detailed in ESMA's September 2013 final technical advice to the European Commission regarding the US regulatory framework (ESMA 2013). One problem concerned the duplicative or conflicting requirements regarding the clearing obligation and risk-mitigation techniques for uncleared OTC derivative contracts. However, the recognition of third-country CCPs was a key concern. The mandatory offloading of derivatives to the perceived safety of centralised clearing creates much new business for CCPs but there is also a risk that the competitive environment pressures CCPs to lower their risk management requirements. These concerns were clearly spelled out in the Commission's EMIR impact assessment, which noted the possibility that regulation could prompt CCPs to compete on risk, that is, compete "through lowering the quality of risk management, more specifically by cutting the margins required from the clearing members" (Commission 2010, p. 68). The deliberations also noted anecdotal evidence supporting this concern:

A number of market participants seem to fear that this is already happening. They have privately told the Commission services on various occasions that CCPs had started lowering their risk standards in order to lower their costs and attract more clients. Recently, a CCP voiced the same concern in public [footnote omitted]. 
These claims were never backed with concrete evidence, so the Commission services cannot judge whether they are true or not. Irrespective of whether they are true or not, however, they highlight a potentially dangerous side effect of competition between CCPs.

The EU Commission and the ESMA were therefore reluctant to declare the US regime for CCPs equivalent. Without such a decision, the ESMA could not recognise US-based CCPs and give them unhindered access to EU clearing markets. Failure to reach an agreement risked further reducing the cross-border-derivative activity between the EU and US. The reason is simple: without a deal, trading and clearing at home would become much cheaper than abroad. For instance, EU Capital Requirements Regulation 575/2013 sets higher capital requirements for transactions that are cleared through a 'non-qualified' (i.e. non-authorised or non-recognised) CCP (Art. 382(3)).

ESMA pushed especially adamantly for a harder approach. It criticised the EU's liberal approach to CCP recognition, noting its extreme openness and excessive reliance on third-country rules and supervisory arrangements (ESMA 2015). In contrast, the US authorities required all third-country CCPs to become subject to the direct jurisdiction of the US authorities (ESMA 2013, pp. 20-21). While the EU's original approach arguably presented a "model in terms of mutual reliance", it worsened Europe's position in the transatlantic bargaining process (ESMA 2013, paras 108-109).

Only on 15 March 2016 - four years after the 'Path Forward Agreement' - did the Commission adopt an equivalence decision concerning the US regulatory framework for central counterparties. The ESMA followed suit, recognising several US-based CCPs between June and December 2016. From there on, things ran apparently smoothly. On 13 October 2017, the European Commission adopted an EMIR equivalence decision for derivative transactions in the United States and thus settled the issue concerning the legal, supervisory and enforcement arrangements for non-centrally-cleared OTC derivative transactions. In particular, the decision covered the rules on risk monitoring and the mandatory exchange of collateral for such contracts. Finally, in December 2017 the Commission adopted an equivalence decision under MiFIR concerning US-based derivative trading venues, therefore ensuring that European market participants could continue to trade derivatives on US platforms.

The bargain was far from complete, however. Soon after the EU reached a political agreement on updating the EMIR in March 2019, tensions over the regulation and supervision of overseas CCPs resurfaced. A struggle to control and oversee London-based CCPs in particular risked undermining the fragile transatlantic agreement. London-based CCPs have for long troubled the eurozone and especially the European Central Bank, which has sought more over- 
sight powers and even threatened to limit the access of London-based CCPs to the eurozone under its controversial Location Policy (Marjosola 2015). This issue has re-intensified because of Brexit (Chamorro-Courtland 2019). The EU is anxious to tighten its grip over London's CCPs, which remain the principal destination for the clearing of euro-denominated derivatives. However, London-based CCPs also handle most of the dollar-denominated derivatives. The EU's new proposal effectively provided that if London-based CCPs wished to continue to clear euro-denominated contracts after Brexit, they would either have to move their business within the EU bloc or accept ESMA's oversight and regulation (Tett 2019).

As Bulfone and Smoleńska show in Chapter 3 in this book, the review of EMIR will bring many crucial changes to the ESMA's powers. In the future, the ESMA will have significantly wider regulatory and supervisory powers, particularly as regards third-country CCPs. ESMA will categorise each third-country CCP as either a non-systemically important CCP (Tier 1 CCP) or a systemically important CCP (Tier $2 \mathrm{CCP}$ ). In the latter case, the relevant CCPs will become subject to additional requirements and the third-country's regulatory and supervisory framework will have to pass much more intense regulatory scrutiny to maintain the equivalence status.

The review of the CCP supervisory and oversight framework re-intensified the transatlantic conflict. The US policymakers and regulators feared that the second generation of EU extraterritoriality, as introduced in the EMIR reform, was targeted not only at London but also at US-based clearing houses. A political agreement in the form of a joint statement between the European Commission and the CFTC - the US swap regulator - managed to ease the tension, but only temporarily (Brunsden and Stafford 2019; Stafford 2019). Despite the standoff, the CFTC managed to reign in its uncompromising requirements for overseas CCPs, allowing limited deference to third-country regulators such as Japan's (Stafford and Rennison 2019).

The position of London in the transatlantic derivative conflict is also telling of the capacity of the post-Brexit UK to engage in regulatory competition vis-à-vis the US and the EU. Hosting systemically important financial market infrastructure, it will have no choice but to concede significant oversight and supervisory powers to both US and European regulators, at least if it wishes to continue servicing market participants from these jurisdictions.

The regulatory turf war between the US and the EU is disconcerting, given that transatlantic communication channels and collaboration venues have been in place for more than ten years. During 2004-2007, the Committee of European Securities Regulators (which later became ESMA) met several times with the CFTC in the context of a joint work programme which explicitly aimed to facilitate the conduct and supervision of transatlantic derivative business. On the other hand, the dispute is less surprising if considered against 
the shifting of bargaining power. The power asymmetry between the Atlantic neighbours has been in steady decline, not least because of the institutional evolution and the centralisation of regulatory authority within the EU (Karmel 2007; Posner 2009). The next section examines what role, if any, the new global regulatory space for OTC derivatives has played in centralising regulatory structures.

\subsection{THE GLOBAL REGULATORY SPACE AND SHIFTING STRUCTURES OF REGULATION}

\subsubsection{Centralisation of Regulatory Authority in the EU}

The purpose of this section is to examine the book's hypothesis that regulatory competition, together with the risk of regulatory arbitrage, prompts regulatory centralisation in internal regulatory structures.

First of all, from the vertical international perspective, the growing importance of global financial regulation constitutes a compelling reason to shift regulatory authority from the Member State level to the EU level. Indeed, the lack of centralised regulatory authority and the inability to speak with one voice have probably held back the development of the European financial markets (Pan 2003). However, as far as the drafting of global financial standards is concerned, the Union is still far from the single representative model, even when it comes to the representation of the eurozone (see De Ryck 2019). The EU is currently a full member of the G20 and so directly represented in the most important standard-setters such as the BSCBs. In addition, the ECB and the SSM (the Banking Union's single supervisory arm hosted by the ECB) are full members of the $\mathrm{BSCB}^{4}$ whereas ESMA is a full member of IOSCO. However, other European G20 members, and some other Member States with developed financial markets, continue to be represented in these forums too.

What is more interesting for the purpose of this chapter is the case for centralisation when it comes to the implementation of international financial standards and G20 policies. The transatlantic turf battle illustrates the formidable task financial regulators face in having to coordinate implementation with their foreign colleagues, whose mandates, reform calendars, priorities and perhaps even incentives are different from their own. As one commissioner from the US Securities and Exchange Commission (SEC) described it:

[...] at no time in the [SEC's] history have we been more engaged with the international community or more involved in collaborative work streams with our fellow regulators from around the globe. Much of this international work stems from the 2009 G20 initiatives regarding over-the-counter (OTC) derivatives reforms. (Piwowar 2014) 
Such international coordination demands are increasing across the spectrum of financial regulations (IOSCO 2015). The need to coordinate the implementation of G20 derivative policy globally first means that implementing powers must be kept at the EU level. It is no surprise that European derivative legislation has been adopted in the form of directly applicable regulations (EMIR and MiFIR). Both acts also include various provisions delegating authority to the European Commission and the ESMA to develop more detailed rules in this area and to deal with the problem of duplicative and conflicting international rules (see, e.g. MiFIR, Article 33). Indeed, in no other area of financial regulation has the ESMA been so active in developing binding technical standards (which the Commission has endorsed without changes) (Moloney 2018, p. 133). To the extent that Member State national authorities have influenced implementation, they have done it through ESMA's governing bodies and working groups.

The need to coordinate implementation internationally therefore provides yet another justification for replacing directives - the EU legislative instrument which by definition leaves implementation of its provisions to Member States - with directly applicable regulations which centralise implementation. On the other hand, as Strand shows in Chapter 4 of this book, there are no significant structural differences between the revised Markets in Financial Instruments Directive (MiFID II) and its sister regulation (MiFIR); MiFID II also centralises implementation by delegating extensive rule-making powers to the Commission and the ESMA, thus narrowing the scope for implementation left to the Member States.

The degree of regulatory centralisation also depends on the amount of power delegated to the ESMA and the Commission. The preceding section showed that regulators on both sides of the Atlantic needed to engage in extensive cross-border negotiations on the final content of their rulebooks in order to achieve the necessary convergence. However, the respective regulators' room for manoeuvre was limited by their legislative mandates. Here, the imbalance of power was considerable. The US federal agencies, such as the SEC and CFTC, have historically enjoyed considerable flexibility and discretion to pursue their tasks, including by issuing binding legal acts. In sharp contrast, constitutional restrictions (the so-called Meroni doctrine) in the EU require that EU agencies such as the ESMA pursue their mandates without a wide margin of discretion and so with much less flexibility (see Bergström 2015; Marjosola 2015). For instance, whereas the SEC and the CFTC can relatively freely roll back or extend the scope of the Dodd-Frank Act's derivative rules, the EU needed to resort to burdensome and lengthy legislative processes to scale back some of the more strenuous provisions of the EMIR. Regulation 2019/834 (EMIR Refit), which entered into force on 17 June 2019, simplified certain areas covered by the EMIR Regulation and introduced "a more 
proportionate approach" in line with the Commission's Regulatory Fitness and Performance programme. In certain areas, such as where it comes to the definition of financial and non-financial counterparties for the purposes of determining the scope of the rules, the amendment brought the rules closer to those in force in the US. Some amendments were explicitly motivated by the need to "enable international regulatory convergence" (see, e.g. recital 21 of the EMIR Refit).

This latter finding about legislative delegations is also interesting from the perspective of another of this book's hypotheses. According to one of the hypotheses presented in Chapter 1, vague legislative provisions contribute to decentralisation or fragmentation of regulatory structures. This chapter suggests that the applicability of this hypothesis should be restricted, at least insofar as it concerns areas in which legislative vagueness is filled with Union-level executive acts such as binding technical standards (and non-binding guidelines and other soft law acts issued by European supervisory authorities). For instance, EMIR has been amplified by more than 30 highly detailed regulatory technical standards ${ }^{5}$ which concern such crucial issues as the criteria to be used when determining which classes of derivatives should be subject to mandatory clearing. Instead of the EMIR determining which derivatives should be cleared through CCPs (a list that would be very hard to draw up ex ante), the EMIR delegates the responsibility to the ESMA and the Commission. ${ }^{6}$

The need to globally coordinate the implementation of financial regulation will pressure the EU legislators to delegate more authority to the European Commission and the ESAs. Indeed, the recent review of the powers and tasks of the European supervisory authorities explicitly referred to both the risk of regulatory arbitrage and the need to coordinate implementation with third-country supervisors as justification for centralising the certain supervisory powers within ESMA. As the recital states, ESMA's role as the Union-wide competent authority "establishes it as the counterpart in the Union for supervisors in third countries, making cross-border cooperation more efficient and effective" (ESA Review, recital 55).

\subsubsection{Consolidation of Regulatory Authority - Lessons from the US}

Increased inter-agency coordination demands in the global arena may also prompt consolidation of regulatory authority horizontally within jurisdictions. As mentioned previously, shared regulatory spaces created by overlapping and duplicative delegations are a common phenomenon in national and regional contexts, for example where multiple agencies are delegated similar functions, or where agencies regulate different products or activities but with a shared purpose (Freeman and Rossi 2011, pp. 1145-1148). The US financial regula- 
tory structure provides a popular example of such a shared regulatory space. In the US, the competence in the field of derivatives is shared between the SEC and the CFTC; the CFTC is the primary regulator for OTC swaps while the SEC regulates security-based swaps, and the agencies regulate 'mixed swaps' jointly. Recognising the functional overlap, the Dodd-Frank Act requires the agencies to coordinate and consult not only with each other but also with other relevant regulators before commencing rulemaking in the area of derivatives (see GAO 2011, p. 23). Such a fragmented regulatory structure with several regulators and overlapping mandates is a historical feature of the entire US financial regulatory structure. For instance, five federal agencies share the responsibility for regulating depository institutions, which can also be regulated by state regulators (Pan 2011, p. 837).

Such overlapping and multiple delegations can result in various weaknesses in terms of efficiency, effectiveness and accountability, alongside certain possible advantages (Freeman and Rossi 2011, pp. 1150-1151). Freeman and Rossi argue that shared regulatory spaces are less problematic than is often thought, and that the case for consolidating 'redundant' agencies under one roof has been significantly oversold in the academic literature. Their argument is that such mergers might simply "convert an interagency coordination problem into an intra-agency problem" (Freeman and Rossi 2011, p. 1154) and that the debate so far has neglected the ability of different coordination tools to mitigate inter-agency coordination problems.

A significant blind spot in Freeman and Rossi's analysis, particularly as it concerns the regulation of derivatives, is that it ignores the cross-border context. As this chapter has shown, the regulatory space for financial derivatives post-G20 reforms transcends jurisdictional borders. In these contexts, the lack of clarity as to which of the US government branches, departments or agencies is responsible for implementing policy - and the fact that they often disagree on policy issues - is obviously much more problematic (see also Riles 2014, p. 81). The SEC and the CFTC have traditionally followed very different regulatory philosophies (Markham 2003) and they have a history of engaging in dysfunctional turf battles (Pan 2008, p. 243). Anecdotal evidence suggests that such inter-agency rivalry between the SEC and CFTC has not been absent in the regulatory space for derivatives either (see Piwowar 2014).

More efficient use of coordination tools could no doubt help overcome such coordination problems, as Freeman and Rossi (2011) suggest, but the transatlantic derivative narrative has also shown that multiple and overlapping delegations make it challenging to speak with one voice in cross-border negotiations (Brummer 2013, pp. 13-14). In its equivalence assessment, the ESMA also recognised the challenges arising from the fact that the implementation of derivative rules was not adequately synchronised between the CFTC and SEC. 
Therefore, the growing need to also share regulatory space internationally might strengthen the case for agency consolidation.

In the $\mathrm{EU}$, the implementation of derivative reforms lands relatively clearly within the substantive remit of the ESMA, and there has been much less need to coordinate the reforms with the other European agencies and bodies forming the European System of Financial Supervision. Another thing entirely is that the European agencies are executive rather than regulatory in nature. As the preceding section noted, ESMA and the other ESAs are relatively toothless when compared to independent regulatory agencies such as the SEC and the CFTC. Indeed, when it comes to making policy deals such as the 2013 Path Forward agreement, the ESMA has primarily played an advisory role. The European Commission still has the final authority to enter such deals. However, the new EMIR rules will take a significant step forward in both centralising and consolidating authority within the ESMA regarding third-country CCPs. Apart from monitoring equivalence, ESMA's new Supervisory Committee will be vested with direct supervisory powers over third-country CCPs. The Supervisory Committee may even withdraw the recognition of a systemically important (Tier 2) CCP and thus force its mandatory relocation to the EU (see also Chapter 3 by Bulfone and Smoleńska in this book).

\subsection{FROM UNILATERALISM TO BILATERALISM AND BEYOND}

This penultimate section will briefly consider certain drawbacks of the above-examined unliteral regulatory strategies and assess their possible implications for financial regulatory structures. First, deference strategies require regulators to continually vet foreign regulatory structures and monitor foreign supervision and enforcement. This is a complex and costly exercise (Jackson 2015). For instance, ESMA's technical advice about the equivalence of the US regime for derivatives includes a line-by-line comparison table covering more than 200 pages followed by more than 1,000 footnotes. The ESMA has itself noted the "extremely rigid and burdensome" nature of the recognition process for third-country CCPs and the equivalence decision process (ESMA 2015, para. 115). The rigidity of the substituted compliance process in the US has also been criticised. In an opinion on the final rules on the international application of standards, one CFTC commissioner noted that "the Commission has embarked on a cross-border analysis that I fear is taking us down a path of regulatory detail that is overly burdensome, complicated, and unnecessary" (CFTC 2013b, p. 881, dissenting statement by Commissioner Jill E. Sommers). As Chris Brummer (2013, p. 5) has noted, such "check-the-box metrics [...] can become quickly outdated in a fast-paced financial marketplace". 
The EU's equivalence regime, which also covers several areas other than derivatives, has produced more than 200 equivalence decisions assessing a total of 32 jurisdictions (European Commission 2017a). There is little indication of how the EU will manage to oversee the developing rulebooks in all these jurisdictions or make sure that the rules that are in place are backed by adequate enforcement and supervision (see also Brummer 2013, p. 5).

A less-intrusive and outcomes-focused approach would demand fewer resources but it would also require mutual trust, which in the absence of credible commitment will be hard to kindle. As the transatlantic derivative dispute illustrates, without binding international standards or organisations enforcing them, regulators' commitments are vulnerable to political reconsiderations and compromises (Brummer 2013, pp. 115-116, 136). Indeed, the difficult cross-border politics of derivative regulation reflects the relatively weak status of transnational regulatory institutions in securities and financial regulation (Posner 2018).

On the other hand, such coordination and monitoring costs will probably not prevent achieving the main advantage of unilateral regulatory strategies. Deference strategies, combined with the sticks of extraterritoriality and protectionism, provide an effective way to export regulatory rules and practices to 'weaker' states (see Raustiala 2002, pp. 7-9). Official EU documentation even explicitly acknowledges this purpose, noting that "a possible equivalence finding by the $\mathrm{EU}$ is one of the major incentives for third-country regulators to enhance supervisory co-operation and to seek closer regulatory convergence with the EU' (European Commission 2017a, p. 4, emphasis added). Indeed, despite the declining importance of the US and the EU as the primary loci of global capital markets (Cox 2012; Brummer 2013, p. 7; Lannoo 2013, p. 21), they together still account for roughly 90 per cent of the market for derivatives (Stafford 2015). Therefore, a deeper transatlantic partnership would force other jurisdictions to converge towards US-EU standards.

However, the coordination problems will not be solved simply by turning a unilateral regulatory strategy into a bilateral one. A joint EU-US leadership would only increase the coordination demands between the Atlantic partners, which would need to act in concert towards the rest of the world. Moreover, as we have already seen, the competitive pressure for market share would constantly risk disintegrating the informal alliance. What such considerations make clear, however, is that when it comes to fields of financial regulation such as derivatives, there are few centrifugal forces affecting the regulatory structures. On the contrary, many have proposed hardening the soft mode of global financial governance with more hierarchical and hard-law structures (see, e.g., Avgouleas 2012; Lastra 2014; Artamonov 2015). 


\subsection{CONCLUSIONS}

The findings in this chapter support the hypothesis that the highly contested global regulatory space for OTC derivatives has contributed to the centralisation of regulatory structures in the European Union. Regulatory competition and the risk of regulatory arbitrage have provided explicit justifications for centralising regulatory and supervisory powers in the Commission and the ESMA. The transatlantic coordination exercise has emphasised the need to be able to negotiate in cross-border dialogues with one voice and with a clear mandate. The need to share regulatory space globally therefore also strengthens the case for consolidating regulatory authority horizontally within jurisdictions.

A number of lessons can be drawn from the regulatory turf battle between the US and the EU. First, global reforms should already be coordinated better when drafting legislation. Second, the executive authorities in charge of coordinating implementation with their foreign colleagues should have broad enough, functional and compatible mandates. In the EU, however, constitutional restrictions limit the delegation of a wide degree of discretion to the executive bodies. This means that more significant fine-tuning - as evidenced by the recently updated EMIR - will have to go through Union legislative bodies also in the future. Closing the transatlantic deal on OTC derivatives would be crucial to stop or at least slow down the ongoing market fragmentation and to counter the immediate regulatory arbitrage threats. For the time being, the EU and the US seem able to use their dominant positions in the markets for derivatives to export their rules overseas. In the longer run, such a 'regulate thy neighbour' model of global financial governance is far from optimal, not least due to its large monitoring and coordination costs. Such problems have increased calls to also centralise regulatory powers globally.

\section{NOTES}

1. This chapter is partly based on Marjosola, H. 2016, Regulate thy neighbour: competition and conflict in the cross-border regulatory space for OTC derivatives. Working Paper, EUI LAW, 2016/01, European Regulatory Private Law Project (ERPL-16).

2. Margins comprise an 'initial margin', a fixed component paid up front and a 'variation margin', which is paid periodically based on changes in the value of open positions (Feder 2002, pp. 733-734).

3. For the complex process of developing the respective derivative rules by the CFTC and SEC, see especially Artamonov 2015; Coffee 2014; Greene and Potiha 2012 and Greene and Potiha 2013.

4. The EBA and the Commission have observer status. 
5. See the list of binding technical standards on ESMA's website: https://www. esma .europa.eu/convergence/guidelines-and-technical-standards (last visited 10 September 2019).

6. On the other hand, this 'top-down' approach is complemented by a 'bottom-up' approach according to which the scope of clearing is partly based on the classes of derivatives already cleared by authorised or recognised CCPs (see EMIR Article $5(2)$ ). This suggests a level of decentralisation, but one that also sidesteps national authorities by relying instead on market participants.

\section{BIBLIOGRAPHY}

Artamonov, A 2015, 'Cross-border application of OTC derivatives rules: revisiting the substituted compliance approach,' Journal of Financial Regulation, vol. 1, no. 2, pp. 206-225.

Avgouleas, E 2012, Governance of Global Financial Markets: The Law, the Economics, the Politics, Cambridge: Cambridge University Press.

Barnier, M 2013, 'International cooperation: a sine qua non for the success of OTC derivatives markets reform,' in OTC Derivatives: New Rules, New Actors, New Risks; Banque de France, Financial Stability Review, no. 17, pp. 41-46.

Beck, T, Coyle, D, Seabright, P and Freixas, X 2010, 'Bailing out the banks: reconciling stability and competition,' Centre for Economic Policy Research, London, 18 February. https://voxeu.org/content/bailing-out-banks-reconciling-stability-and -competition (last accessed 14 April 2020).

Bergström, CF 2015, 'Shaping the new system for delegation of powers to EU agencies: United Kingdom v. European Parliament and Council (Short selling), 'Common Market Law Review, vol. 52, no. 1, pp. 219-242.

Braithwaite, JP 2012, 'Standard form contracts as transnational law: evidence from the derivatives markets,' The Modern Law Review, vol. 75, no. 5, pp. 779-805.

Brummer, C 2010, 'Territoriality as a regulatory technique: notes from the financial crisis,' University of Cincinnati Law Review, vol. 79, no. 2, pp. 499-526.

Brummer, C (rapporteur) 2013, 'The danger of divergence: transatlantic financial reform $\&$ the G20 agenda' (a report prepared for the Atlantic Council, Thomson Reuters and TheCityUK). Washington: the Atlantic Council. https://www.atlanticcouncil.org/ in-depth-research-reports/report/the-danger-of-divergence-transatlantic-financial -reform-the-g20-agenda/ (last visited 14 April 2020).

Brunsden, J and Stafford, P 2019, 'EU asserts power over City's euro clearing role,' The Financial Times, 13 March, FT Trading Room.

Buxbaum, HL 2002, 'Conflict of economic laws: from sovereignty to substance,' Virginia Journal of International Law, vol. 42, no. 4, pp. 931-977.

Carney, M 2013, 'Completing the G20 reform agenda for strengthening over-the-counter derivatives markets,' in OTC Derivatives: New Rules, New Actors, New Risks; Banque de France, Financial Stability Review, no. 17, pp. 11-18.

Carruthers, BG 2013, 'Diverging derivatives: law, governance and modern financial markets,' Journal of Comparative Economics, vol. 41, no. 2, pp. 386-400.

CESR. 2015, Press Release, 'Committee of European Securities Regulators and the US CFTC meet to facilitate transatlantic derivatives business and to appoint task force to develop further efforts' (Ref. 05-096), 14 February 2005.

CESR-CFTC. 2005, 'Communiqué, CESR-CFTC Common Work Program to Facilitate Transatlantic Derivatives Business,' 28 June 2005 (available at https://www.esma 
.europa.eu/document/cesr-cftc-common-work-program-facilitate-transatlantic -derivatives-business) (last accessed 14 April 2020).

CFTC. 2012, "Further definition of "swap dealer," "security-based swap dealer," "major swap participant," "major security-based swap participant" and "eligible contract participant," Federal Register, vol. 77, no. 100, 23 May 2012, rules and regulations.

CFTC. 2013a 'Cross-border security-based swap activities: re-proposal of Regulation SBSR and certain rules and forms relating to the registration of security-based swap dealers and major security-based swap participants,' Federal Register, vol. 78, no. 100, 23 May 2013, proposed rules.

CFTC. 2013b, 'Final exemptive order regarding compliance with certain swap regulations (Dec. 20, 2012),' Federal Register, vol. 78, no. 4, Monday 7 January 2013, rules and regulations https://www.govinfo.gov/content/pkg/FR-2013-01-07/pdf/ 2012-31736.pdf (last accessed 14 April 2020).

CFTC. 2013c, Press release, 'The European Commission and the CFTC reach a common path on derivatives,' 11 July 2013, http://www.cftc.gov/PressRoom/ PressReleases/pr6640-13 (last accessed 14 April 2020).

CFTC. 2014, J Christopher Giancarlo, Commissioner of the CFTC, Keynote Address at The Global Forum for Derivatives Markets, 35th Annual Burgenstock Conference, Geneva Switzerland, 24 September 2014.

Chamorro-Courtland, C 2019, 'Brexit scenarios: the future of clearing in Europe,' Columbia Journal of European Law, vol. 25, p. 169.

Choi SJ and Gulati GM 2006, 'Contract as statute,' Michigan Law Review, vol. 104, no. 5, pp. 1129-1173.

Coffee JC Jr 2014, 'Extraterritorial financial regulation: why ET can't come home,' Cornell Law Review, vol. 99, no. 6, pp. 1259-1302.

Cox, J 2012, 'The extraterritorial reach of the US financial laws,' in E Wymeersch, KJ Hopt and G Ferrarini (eds), Financial Regulation and Supervision: A Post-Crisis Analysis, Oxford: Oxford University Press, Chapter 15 (Kindle edition).

De Ryck, P 2019, 'Towards unified representation for the euro area within the IMF,' European Parliamentary Research Service, PE 637.969, July 2019.

Deutsche Börse and Eurex Clearing 2014, 'How central counterparties strengthen the safety and integrity of financial markets?' July 2014. https://www.deutsche-boerse .com/resource/blob/78994/37fbffb2a577d8e43d52d19223b49c63/data/how-central -counter-parties-strengthen-the-safety-and-integrity-of-financial-markets_de.pdf (last accessed 14 April 2020).

ESMA. 2013. Final Report: Technical advice on third country regulatory equivalence under EMIR - US, ESMA/2013/115, 1 September 2013.

ESMA. 2014. Report (final) on draft regulatory technical standards on direct, substantial and foreseeable effect in the EU, endorsed by the European Commission on 13 February 2014, Commission Delegated Regulation (EU) No 285/2014.

ESMA. 2015, EMIR Review Report no. 4 (2015/1254), 2015.

European Commission. 2010, EMIR Impact Assessment 2010, EMIR.

European Commission. 2017a, Staff Working Document: EU equivalence decisions in financial services policy: an assessment, p. 4, Brussels, 27 February 2017, SWD (2017) 102 final.

European Commission. 2017b, Press Release, 'Commission adopts EMIR equivalence decision for derivatives transactions in the United States,' Brussels, 13 October 2017. 
FCIC. 2011, Financial Crisis Inquiry Commission, Report (The FCIC Report). https:// www.govinfo.gov/content/pkg/GPO-FCIC/pdf/GPO-FCIC.pdf (last accessed 14 April 2020).

Feder, NM 2002, 'Deconstructing over-the-counter derivatives,' Columbia Business Law Review, vol. 2000, no. 3, pp. 677-748.

Freeman, J and Rossi, J 2011, 'Agency coordination in shared regulatory space,' Harvard Law Review, vol. 125, no. 5, pp. 1131-1211.

FSB. 2010, Financial Stability Board, 'Implementing OTC derivatives market reforms,' report, 25 October 2010.

FSB. 2012, Financial Stability Board, meeting in November 2012, joint press statement 'Operating principles and areas of exploration in the regulation of the cross-border OTC derivatives market,' December 2012.

FSB. 2015, Financial Stability Board, OTC derivatives market reforms, tenth progress report on implementation, 4 November 2015.

FSB. 2017, Financial Stability Board, 'Review of OTC derivatives market reforms, effectiveness and broader effects of the reforms,' 29 June 2017.

FSB. 2018, Financial Stability Board, 'Implementation and effects of the G20 financial regulatory reforms,' 4th Annual Report, 28 November 2018.

G20. 2009, G20 Leaders' Statement: The Pittsburgh Summit, 24-25 September 2009, Pittsburgh. http://www.g20.utoronto.ca/2009/2009communique0925.html (Last visited 14 April 2020).

G20. 2013, G20 Leaders' Declaration, St. Petersburg Summit, 5-6 September 2013. https://g20.org/en/g20/Documents/2013-Russia-G20\%20Leaders_\%20Declaration .pdf (Last visited 14 April 2020).

GAO. 2011, United States Government Accountability Office, 'Financial derivatives, disparate tax treatment and information gaps create uncertainty and potential abuse,' September 2011.

Godwin, A, Ramsay, I and Sayes, E 2017, 'Assessing financial regulatory coordination and integration with reference to OTC derivatives regulation,' Capital Markets Law Journal, vol. 12, no. 1, pp. 38-65.

Goodhart, CA and Lastra, RM 2010, 'Border problems,' Journal of International Economic Law, vol. 13, no. 3, pp. 705-718.

Greene, EF and Potiha, I 2012, 'Examining the extraterritorial reach of Dodd-Frank's Volcker rule and margin rules for uncleared swaps - a call for regulatory coordination and cooperation,' Capital Markets Law Journal, vol. 7, no. 3, pp. 271-316.

Green, EF and Potiha, I 2013, 'Issues in the extraterritorial application of Dodd-Frank's derivatives and clearing rules, the impact on global markets and the inevitability of cross-border and US domestic coordination.' Capital Markets Law Journal, vol. 8, no. 4 , pp. 338-394.

Hancher, L and Moran, M 1998, 'Organizing regulatory space,' in R Baldwin, C Scott and C Hood (eds), A Reader on Regulation, Oxford: Oxford University Press, Chapter 3.

Hu, HTC 1993, 'Misunderstood derivatives: the causes of informational failure and the promise of regulatory incrementalism,' Yale Law Journal, vol. 102, no. 6, pp. 1457-1513.

Hull, JC 2011, Options, Futures, and Other Derivatives, 8th edition, Pearson College Division.

Institute of International Finance (IIF). 2019, 'Addressing market fragmentation: the need for enhanced global regulatory cooperation,' January 2019. https://www.iif 
.com/Portals/0/Files/IIF\%20FSB\%20Fragmentation\%20Report.pdf (last accessed 14 April 2020).

IOSCO. 2015, 'Task force on cross-border regulation final report,' FR 23/2015, September 2015. https://www.iosco.org/library/pubdocs/pdf/IOSCOPD507.pdf (last accessed 14 April 2020)

IOSCO. 2019, 'Market fragmentation \& cross-border regulation,' Report. FR07/2019, June 2019. https://www.iosco.org/library/pubdocs/pdf/IOSCOPD629.pdf (last accessed 14 April 2020).

ISDA. 2013, 'Non-cleared OTC derivatives: their importance to the global economy,' March 2013. https://www.isda.org/2013/03/13/non-cleared-otc-derivatives-their -importance-to-the-global-economy/ (last accessed 14 April 2020).

ISDA. 2015, 'Cross-border fragmentation of global derivatives: end-year 2014 update', April 2015. https://www.isda.org/a/EVDDE/market-fragmentation-final.pdf (last accessed 14 April 2020).

Jackson, HE 2015, 'Substituted compliance: the emergence, challenges, and evolution of a new regulatory paradigm,' Journal of Financial Regulation, vol. 1, no. 2, pp. 169-205.

Jain, AG 2014, 'Derivatives as a test case for international financial regulation through the WTO,' Journal of World Trade, vol. 48, no. 1, pp. 135-165.

Joint Statement. 2016, 'Improvements in EU-US regulatory cooperation,' Brussels, 18 July 2016. https://ec.europa.eu/info/sites/info/files/business_economy_euro/ banking_and_finance/documents/160718-eu-us-joint-financial-regulatory-dialogue -joint-statement_en.pdf (last accessed 14 April 2020).

Karmel, RS 2007, 'The EU challenge to the SEC,' Fordham International Law Journal, vol. 31, no. 6, pp. 1692-1712.

Kentz, M 2014, 'Equity derivatives traders warm to OTC,' Reuters, 13 April. https:// www.reuters.com/article/markets-derivatives-otc/equity-derivatives-traders-warm -to-otc-idUSL2N0X71ER20150413 (last accessed 14 April 2020).

Knaack, P 2015, 'Innovation and deadlock in global financial governance: transatlantic coordination failure in OTC derivatives regulation,' Review of International Political Economy, vol. 22, no. 6, pp. 1217-1248.

Lannoo, K 2013, 'The new financial regulatory paradigm: a transatlantic perspective,' CEPS Policy Brief, no. 287, 21 March 2013.

Lastra, RM 2014, 'Do we need a world financial organization?' Journal of International Economic Law, vol. 17, no. 4, pp. 787-805.

Majone, G 1998, 'The rise of the regulatory state in Europe,' in R Baldwin, C Scott and C Hood (eds), A Reader on Regulation, Oxford: Oxford University Press, Chapter 5.

Marjosola, H 2014, 'Bridging the constitutional gap in EU executive rule-making: the Court of Justice approves legislative conferral of intervention powers to European securities and Markets Authority: Case C-270/12, UK v. Parliament and Council (Grand Chamber),' European Constitutional Law Review, vol. 10, no. 3, pp. 500-527.

Marjosola, H 2015, 'Missing pieces in the patchwork of EU financial stability regime? The case of central counterparties,' Common Market Law Review, vol. 52, no, 6, pp. 1491-1527.

Markham, JW 2003, 'Super regulator: a comparative analysis of securities and derivatives regulation in the United States, the United Kingdom, and Japan,' Brooklyn Journal of International Law, vol. 28, no. 2, pp. 319-410.

McCormick, L 2015, 'Financial firms move closer to central clearing in repo market,' Bloomberg, 13 April 2015. https://www.bloomberg.com/news/articles/2015-04-13/ 
financial-firms-move-closer-to-central-clearing-in-repo-market (last accessed 14 April 2020).

Moloney, N 2018, The Age of ESMA: Governing EU Financial Markets, London: Bloomsbury Publishing.

Pan, EJ 2003, 'Harmonization of US-EU securities regulation: the case for a single European securities regulator,' Law and Policy in International Business, vol. 34, no. 2, pp. 499-536.

Pan, EJ 2008, 'Single stock futures and cross-border access for US investors,' Stanford Journal of Law, Business \& Finance, vol. 12, no. 1, pp. 221-261.

Pan, EJ 2011, 'Structural reform of financial regulation,' Transnational Law \& Contemporary Problems, vol. 19, no. 3, pp. 796-867.

Partnoy, F 1997, 'Financial derivatives and the costs of regulatory arbitrage,' The Journal of Corporate Law, vol. 22, no 2, pp. 211-256.

Partnoy, F 2001, 'The shifting contours of global derivatives regulation,' University of Pennsylvania Journal of International Law, vol. 22, no. 3, pp. 421-495.

Piwowar, MS 2014, 'Toward a global regulatory framework for cross-border OTC derivatives activities,' the Harvard Law School Forum on Corporate Governance and Financial Regulation, 22 March.

Posner, E 2009, 'Making rules for global finance: transatlantic regulatory cooperation at the turn of the millennium,' International Organization, vol. 63, no. 4, pp. 665-699.

Posner, E 2018, 'Financial regulatory cooperation: coordination of derivatives markets,' in E. Helleiner, S Pagliari and I Spagna (eds), Governing the World's Biggest Market: The Politics of Derivatives Regulation after the 2008 Crisis, New York: Oxford University Press, Chapter 2.

Raustiala, K 2002, 'The architecture of international cooperation: transgovernmental networks and the future of international law,' Virginia Journal of International Law, vol. 43, pp. 1-92.

Riles, A 2014, 'Managing regulatory arbitrage: a conflict of laws approach,' Cornell International Law Journal, vol. 47, no. 1, pp. 63-119.

Singh, M 2010, 'Collateral, netting and systemic risk in the OTC Derivatives Market,' IMF Working Paper 10/99.

Singh, M and Aitken, J 2009, 'Counterparty risk, impact on collateral flows and role for central counterparties,' IMF Working Paper 09/173.

Stafford, P 2014, 'Europe calls on US to recognise overseas clearing rules,' The Financial Times, 28 June.

Stafford, P 2015, 'Market calls for US and Europe to end derivatives dispute,' The Financial Times, 2 September.

Stafford, P 2019, 'EU plans to tighten derivatives rules rankles in the US,' The Financial Times, 27 June, Opinion Tail Risk.

Stafford, P and Rennison, J 2019, 'CFTC agrees to rein in rules for overseas clearing houses,' 12 July, The Financial Times, FT Trading Room.

Tafara, E and Peterson, RJ 2007, 'A blueprint for cross-border access to US investors: a new international framework,' Harvard International Law Journal, vol. 48, no. 1, pp. 31-68.

Tett, G 2019, 'A transatlantic front opens in the Brexit battle over derivatives: Britain is caught in the middle of a regulatory tussle between the US and the EU,' The Financial Times, 19 March.

Verdier, P-H 2013, 'The political economy of international financial regulation,' Indiana Law Journal, vol. 88, no. 4, pp. 1405-1474. 
Yen, J and Lai, KK 2014, Emerging Financial Derivatives: Understanding Exotic Options and Structured Products, London: Routledge. 